\title{
GREEN ROUTE FOR THE SYNTHESIS OF OXADIAZOLE DERIVATIVE CONTAINING BENZIMIDAZOLE MOIETY AND ITS MANNICH BASES: IN-VITRO ANTIMICROBIAL ACTIVITY
}

\author{
Samrin Naz ${ }^{*}$ and Mahendra B. Bagade \\ Department of Chemistry, Seth Kesarimal Porwal College, Kamptee-441001, (Maharashtra)India \\ *E-mail: nazsam.mohsin@gmail.com
}

\begin{abstract}
Green method is employed for the synthesis of 5-((1H-benzimidazol-2-ylthio) methyl)-3-(substituted)-1,3,4oxadiazole-2(3H)-thione derivatives by Mannich reaction of 5-((1H-benzimidazol-2-ylthio)methyl)-3-(substituted)1,3,4-oxadiazole-2 $(3 \mathrm{H})$-thione with formaldehyde and different secondary amines . The ${ }^{1} \mathrm{H}$ NMR, FT-IR and mass spectral studies were carried out to assign the structure of newly synthesized compounds. Amongst all tested new compounds, the antimicrobial assay of piperazinyl substituted oxadiazole derivatives showed good in vitro antibacterial activities.
\end{abstract}

Keywords: Mannich Bases, Oxadiazole, Benzimidazole, Microwave Irradiation, Antibacterial Activity.

(C) RASĀYAN. All rights reserved

\section{INTRODUCTION}

Amines are an extremely important group in medicinal chemistry and are present in many drugs. Mannich reaction is a multicomponent condensation reaction in which an active substrate is amino methylated for synthesis and modification of biologically active compounds. As Mannich bases have amine groups, they are physiologically active. The most important use for the Mannich bases is in pharmaceutical industries as they possess antibacterial ${ }^{1-4}$, antifungal ${ }^{5-6}$, anticancer ${ }^{7-10}$, antioxidant ${ }^{11-12}$, antimalarial ${ }^{13}$, antiinflammatory $^{14-15}$, anti-proliferative ${ }^{16}$ and anti-diabetic ${ }^{17}$ properties. Moreover, Mannich bases are important pharmacophores in treating thrombosis caused by antioxidants. ${ }^{18}$ Mannich bases have technological applications in polymer chemistry as paints and surface-active agents. ${ }^{19}$

Amongst heterocycles, benzimidazole is having immense importance. Benzimidazole is the constituent of Vitamin- $\mathrm{B}_{12}$ and many pharmaceutical drugs. This heterocyclic ring system shows numerous biological activities such as antifungal ${ }^{20}$, antibacterial ${ }^{21}$, antioxidant ${ }^{22-23}$, antiparasitic ${ }^{24-25}$, anti-inflammatory ${ }^{26}$, antiproliferative ${ }^{27}$, and anti-HIV ${ }^{28}$. Oxadiazole nucleus is associated with a variety of pharmacological actions and shows prominent antibacterial ${ }^{29}$, anticonvulsant ${ }^{30}$, antifungal ${ }^{31-32}$, and antitubercular ${ }^{33}$ activities.

We have adopted a non-conventional and greener approach for the synthesis of new biologically active compounds by incorporating different pharmacophores in the same unit. A new series of Mannich bases of oxadiazole derivative containing benzimidazole moiety was synthesized using microwave irradiation technique. This technique is a method of accelerated organic synthesis of the compounds in a short time with good yield and provides a greener alternative to the conventional methods. In this new series, the exchangeable hydrogen atom of the $\mathrm{NH}$ group in oxadiazole moiety is substituted with an amine through a methylene bridge by Mannich reaction under microwave radiation.

\section{Materials and Methods}

\section{EXPERIMENTAL}

Analytical grade reagents and solvents were used for the present work and were not purified further. The melting points of the synthesized compound $\mathbf{4}$ and 5a-g were recorded using the melting point apparatus.

Rasayan J. Chem., 13(1), 370-376(2020)

http://dx.doi.org/10.31788/RJC.2020.1315343

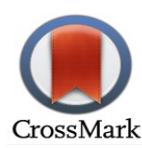




\section{RASĀYAN J. Chem. \\ Vol. 13 | No. 1 |370 - 376| January - March | 2020}

Precoated TLC plates (Merck) were used to confirm the completion of the reaction. The obtained TLC spots were visualized using iodine vapors. Crystallization was used as a technique for the purification of newly synthesized compounds. IR spectra $\left(v_{\max } \mathrm{cm}^{-1}\right)$ were measured on the Shimadzu FT-IR spectrophotometer using solid $\mathrm{KBr}$ pellets. Bruker Advance II $400 \mathrm{MHz}$ was used for recording ${ }^{1} \mathrm{H}$ NMR chemical shifts in ppm. $\mathrm{CDCl}_{3^{-}}$DMSO $\mathrm{d}_{6}$ was used as a solvent and tetramethylsilane (TMS) as an internal standard. A domestic microwave oven of output energy range from $140 \mathrm{~W}$ to $900 \mathrm{~W}$ was used for carrying out reaction under microwave irradiation.

\section{General Procedure}

Synthesis of Ethyl 2-(1H-benzimidazol-2-ylthio) acetate (2)

$1.50 \mathrm{~g}$ of $1 \mathrm{H}$-benzimidazole-2-thiol $(0.01 \mathrm{~mol})$ and $1.22 \mathrm{ml}$ ethyl 2-chloroacetate $(0.01 \mathrm{~mol})$ in acetone along with $1 \mathrm{~g}$ anhydrous $\mathrm{K}_{2} \mathrm{CO}_{3}$ were irradiated at $350 \mathrm{~W}$ power for 3.5 minutes. When the reaction completed, checked by TLC, the reaction mixture was treated with water. The product obtained was recrystallized to give compound 2 ; yield: $82 \%$; M.P. $60^{\circ} \mathrm{C}$.

\section{Synthesis of 2-(1H-benzimidazol-2-ylthio) acetohydrazide (3)}

$2.36 \mathrm{~g}$ of ethyl $2-(1 \mathrm{H}$-benzimidazol-2-ylthio $)$ acetate $(0.01 \mathrm{~mol})$ and $0.9 \mathrm{ml}$ of hydrazine monohydrate $(0.01 \mathrm{~mol})$ in ethanol was irradiated at $300 \mathrm{~W}$ power for 4.0 minutes. The reaction mixture was kept at 8$10^{\circ} \mathrm{C}$ for about $1 \mathrm{~h}$, the separated solid was recrystallized with an appropriate solvent to furnish compound 3; yield: $60 \%$; M.P. $195^{\circ} \mathrm{C}$

\section{Synthesis of 5-((1H-benzimidazol-2-ylthio)methyl)-1,3,4-0xadiazole-2(3H)-thione(4) \\ Conventional Method}

$0.01 \mathrm{~mol}$ of 2-(1H-benzimidazol-2-ylthio) acetohydrazide was taken in a solution of $0.015 \mathrm{~mol}$ of $\mathrm{KOH}$ in $20 \mathrm{ml}$ Ethanol. This was treated with $0.015 \mathrm{~mol}$ of $\mathrm{CS}_{2}$. This mixture was diluted with $15 \mathrm{ml}$ of absolute ethanol. It was stirred at $30^{\circ}-35^{\circ} \mathrm{C}$ for $14-16 \mathrm{~h}$. As the reaction completed (monitored by TLC), it was treated with dil $\mathrm{HCl}$ under cold condition. The precipitated yellow product was filtered. Recrystallization of the crude product with absolute ethanol gave compound 4. M.P. $176-178^{\circ} \mathrm{C}$

\section{Microwave Method}

$10 \mathrm{mmol}$ of 2-(1H-benzimidazol-2-ylthio) acetohydrazide was treated with $15 \mathrm{mmol}$ of $\mathrm{KOH}$ and 15 mmol of $\mathrm{CS}_{2}$ using a minimum amount of ethanol. The reaction mixture was irradiated at $400 \mathrm{~W}$ power for nearly 4 minutes. When the reaction completed confirmed by TLC, it was just acidified with dil $\mathrm{HCl}$ under cold condition. The yellow product precipitated in high yield. The product was purified by crystallization with ethanol to obtain compound 4.

M.P. $176-178^{\circ} \mathrm{C}$; IR (KBr, $\left.v_{\max }\right)$ : 3349.8, 3129(-NH-), 1672.5(C=N), 1523.8(Ar C=C), 1454(C=S), 1262

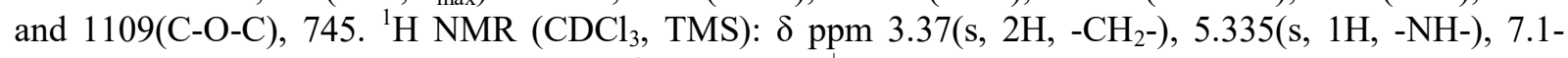
7.3(m, 4H, Ar), 7.58(s, 1H, -NH-). MS: m/z 265[M+H] $]^{+}$.

\section{General Method for Synthesis of Mannich Bases (5a-g) \\ Conventional Method}

$1 \mathrm{mmol}$ of 5-((1H-benzimidazol-2-ylthio)methyl)-1,3,4-oxadiazole-2(3H)-thione was dissolved in $10 \mathrm{ml}$ of ethanol. To this $1.5 \mathrm{mmol}$ of $\mathrm{HCHO}$ and $1 \mathrm{mmol}$ of appropriate amine were added. On magnetic stirrer, the reaction mixture was stirred at $25-30^{\circ} \mathrm{C}$ for the required time given in table 1 . The obtained crude products were recrystallized with absolute ethanol to get compounds 5a-g.

\section{Microwave Method}

$1 \mathrm{mmol}$ of appropriate amine, $1.5 \mathrm{mmol}$ of $\mathrm{HCHO}$ and $1 \mathrm{mmol}$ of compound 4 were dissolved in the minimum amount of ethanol. The reaction mixture was irradiated in a microwave oven till completion of the reaction (1-4 min), confirmed by TLC. The separated products were recrystallized with absolute ethanol to get compounds 5a-g. 
RASĀYAN J. Chem.

Vol. 13 | No. 1 |370 - 376| January - March | 2020

Spectroscopic Data of Compound 5a-g

5-((1H-Benzimidazol-2-ylthio)methyl)-3-(morpholinomethyl)-1,3,4-oxadiazole-2(3H)-thione (5a)

M.P. $158-160^{\circ} \mathrm{C}$; IR (KBr, $\left.v_{\max } \mathrm{cm}^{-1}\right): 2957(\mathrm{Ar} \mathrm{C}-\mathrm{H}), 2865(\mathrm{C}-\mathrm{H}), 1618(-\mathrm{C}=\mathrm{N}-), 1440(-\mathrm{C}=\mathrm{S}), 1323(-\mathrm{C}-\mathrm{N}-$ ), 1161(-C-O-C-), 750. ${ }^{1} \mathrm{H}$ NMR (DMSO- $d_{6}$, TMS): $\delta \mathrm{ppm} 2.515\left(\mathrm{t}, 4 \mathrm{H},-\mathrm{CH}_{2}-\right)$ 3.4(s, $\left.2 \mathrm{H},-\mathrm{CH}_{2}-\right), 4.6(\mathrm{~s}$, $\left.2 \mathrm{H},-\mathrm{CH}_{2}-\right), 4.8\left(\mathrm{~s}, 2 \mathrm{H},-\mathrm{CH}_{2}-\right), 7.2-7.6(\mathrm{~m}, 4 \mathrm{H}, \mathrm{Ar}) . \mathrm{MS}: \mathrm{m} / \mathrm{z} 364[\mathrm{M}-\mathrm{H}]$.

5-((1H-Benzimidazol-2-ylthio)methyl)-3-(pyrrolidin-1-ylmethyl)-1,3,4-oxadiazole-2(3H)-thione (5b) M.P. $205-207^{\circ} \mathrm{C}$; IR (KBr, $\left.v_{\max } \mathrm{cm}^{-1}\right)$ : 3025(Ar C-H), 2962(C-H stretching), 1620(-C=N-), $1330(-\mathrm{C}-\mathrm{N}-)$, 1437(-C=S), $1202(\mathrm{C}-\mathrm{O}-\mathrm{C}), 755,739 .{ }^{1} \mathrm{H}$ NMR (DMSO- $d_{6}$, TMS): $\delta \mathrm{ppm} 1.6\left(\mathrm{t}, 4 \mathrm{H},-\mathrm{CH}_{2}-\right), 2.20(\mathrm{t}, 4 \mathrm{H},-$ $\left.\mathrm{CH}_{2^{-}}\right), 4.5\left(\mathrm{~s}, 2 \mathrm{H},-\mathrm{CH}_{2^{-}}\right), 5.01\left(\mathrm{~s}, 2 \mathrm{H},-\mathrm{CH}_{2^{-}}\right), 7.27-7.65$ (m, 4H, Ar). MS: m/z 348[M+H] $]^{+}$.

\section{5-((1H-Benzimidazol-2-ylthio)methyl)-3-((dimethylamino)methyl)-1,3,4-oxadiazole-2(3H)-thione}

(5c)

M.P. $186-188^{\circ} \mathrm{C}$; IR $\left(\mathrm{KBr}, v_{\max } \mathrm{cm}^{-1}\right)$ : 3060(Ar $\left.-\mathrm{C}-\mathrm{H}\right), 2892(\mathrm{C}-\mathrm{H}$ stretching), $1650(\mathrm{C}=\mathrm{N}), 1600(\mathrm{C}=\mathrm{C})$, $1440(\mathrm{C}=\mathrm{S}), 1335(\mathrm{C}-\mathrm{N}), 1221(\mathrm{C}-\mathrm{O}-\mathrm{C}), 750 .{ }^{1} \mathrm{H}$ NMR (DMSO- $\left.d_{6}, \mathrm{TMS}\right): \delta \mathrm{ppm} 2.3\left(\mathrm{~s}, 6 \mathrm{H}, \mathrm{CH}_{3}\right), 2.9(\mathrm{~s}$, $\left.4 \mathrm{H},-\mathrm{CH}_{2}-\right), 4.84\left(\mathrm{~s}, 2 \mathrm{H},-\mathrm{CH}_{2}-\right), 5.12\left(\mathrm{~s}, 2 \mathrm{H},-\mathrm{CH}_{2^{-}}\right), 7.3-7.72(\mathrm{~m}, 4 \mathrm{H}, \mathrm{Ar}) . \mathrm{MS}: \mathrm{m} / \mathrm{z} 322[\mathrm{M}+\mathrm{H}]^{+}$.

5-((1H-Benzimidazol-2-ylthio)methyl)-3-((diethylamino)methyl)-1,3,4-oxadiazole-2(3H)-thione (5d) M.P. $230-232^{\circ} \mathrm{C}$; IR $\left(\mathrm{KBr}, v_{\max } \mathrm{cm}^{-1}\right)$ : 3220( $\left.\mathrm{Ar}-\mathrm{C}-\mathrm{H}\right), 2924\left(\mathrm{C}-\mathrm{H}\right.$ stretching), $2872\left(\mathrm{CH}_{3}\right), 1623(-\mathrm{C}=\mathrm{N}-)$, 1588(-C=C-), 1437(-C=S), 1295(-C-N-), 1212(-C-O-C-), 740, 706. ${ }^{1} \mathrm{H}$ NMR (DMSO-d 6 , TMS): $\delta$ ppm $1.2\left(\mathrm{t}, 6 \mathrm{H},-\mathrm{CH}_{2}-\right), 2.45\left(\mathrm{q}, 4 \mathrm{H},-\mathrm{CH}_{2}-\right), 4.1\left(\mathrm{~s}, 2 \mathrm{H},-\mathrm{CH}_{2}-\right), 5.26\left(\mathrm{~s}, 2 \mathrm{H},-\mathrm{CH}_{2}-\right), 7.32-7.65(\mathrm{~m}, 4 \mathrm{H}, \mathrm{Ar}) . \mathrm{MS}$ : $\mathrm{m} / \mathrm{z} 350[\mathrm{M}+\mathrm{H}]^{+}$.

5-((1H-Benzimidazol-2-ylthio)methyl)-3-(piperidin-1-ylmethyl)-1,3,4-oxadiazole-2(3H)-thione (5e) M.P. $256-258^{\circ} \mathrm{C}$; IR (KBr, $\left.v_{\max } \mathrm{cm}^{-1}\right)$ : 3236(Ar $\left.-\mathrm{C}-\mathrm{H}\right), 2854(-\mathrm{C}-\mathrm{H}$ stretching), 1633(-C=N-), 1488(-C=C-),

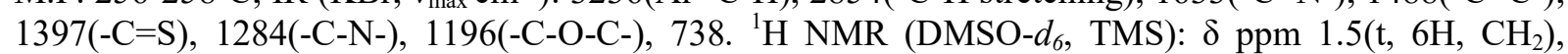
2.24(t, $\left.4 \mathrm{H},-\mathrm{CH}_{2}-\right), 4.34\left(\mathrm{~s}, 2 \mathrm{H},-\mathrm{CH}_{2}-\right), 5.3\left(\mathrm{~s}, 2 \mathrm{H},-\mathrm{CH}_{2}-\right), 7.4-7.7(\mathrm{~m}, 4 \mathrm{H}, \mathrm{Ar}) . \mathrm{MS}: \mathrm{m} / \mathrm{z} 362[\mathrm{M}+\mathrm{H}]^{+}$.

5-((1H-Benzimidazol-2-ylthio)methyl)-3-((4-methylpiperazin-1-yl)methyl)-1,3,4-oxadiazole-2(3H)thione (5f)

M.P. $245-247^{\circ} \mathrm{C}$; IR (KBr, $\left.v_{\max } \mathrm{cm}^{-1}\right)$ : $3105(\mathrm{Ar}-\mathrm{C}-\mathrm{H}), 2806(-\mathrm{C}-\mathrm{H}$ stretching), $1658(-\mathrm{C}=\mathrm{N}-), 1560(-\mathrm{C}=\mathrm{S})$, 1320(-C-N-), 1247(-C-O-C-), 748, 742, 723. ${ }^{1} \mathrm{H}$ NMR (DMSO- $d_{6}$, TMS): $\delta$ ppm 2.27(t, 3H, $\left.\mathrm{CH}_{3}\right), 2.46(\mathrm{t}$, $\left.8 \mathrm{H},-\mathrm{CH}_{2}-\right), 4.67\left(\mathrm{~s}, 2 \mathrm{H},-\mathrm{CH}_{2}-\right), 4.86\left(\mathrm{~s}, 2 \mathrm{H},-\mathrm{CH}_{2}-\right), 7.33-7.82(\mathrm{~m}, 4 \mathrm{H}, \mathrm{Ar}) . \mathrm{MS}: \mathrm{m} / \mathrm{z} 377[\mathrm{M}+\mathrm{H}]^{+}$.

5-((1H-Benzimidazol-2-ylthio)methyl)-3-((4-ethylpiperazin-1-yl)methyl)-1,3,4-oxadiazole-2(3H)thione (5g)

M.P. $280-282^{\circ} \mathrm{C}$; IR $\left(\mathrm{KBr}, v_{\max }\right.$ in $\left.\mathrm{cm}^{-1}\right)$ : 2980(Ar C-H), 2870(-C-H stretching), $1627(-\mathrm{C}=\mathrm{N}-), 1625(-$ $\mathrm{C}=\mathrm{C}-), 1520(-\mathrm{C}=\mathrm{S}), 1311(\mathrm{C}-\mathrm{N}), 1232(-\mathrm{C}-\mathrm{O}-\mathrm{C}-), 752 .{ }^{1} \mathrm{H}$ NMR (DMSO $d_{6}$, TMS): $\delta \mathrm{ppm} 1.2\left(\mathrm{t}, 3 \mathrm{H}, \mathrm{CH}_{3}\right)$, $2.46\left(\mathrm{t}, 8 \mathrm{H},-\mathrm{CH}_{2}-\right), 2.40\left(\mathrm{q}, 2 \mathrm{H},-\mathrm{CH}_{2}-\right), 4.9\left(\mathrm{~s}, 2 \mathrm{H},-\mathrm{CH}_{2}-\right), 5.59\left(\mathrm{~s}, 1 \mathrm{H},-\mathrm{CH}_{2^{-}}\right), 7.25-7.79(\mathrm{~m}, 4 \mathrm{H}, \mathrm{Ar}) . \mathrm{MS}:$ $\mathrm{m} / \mathrm{z} 391[\mathrm{M}+\mathrm{H}]^{+}$.

\section{Antimicrobial Activity}

The in vitro antibacterial assay of newly synthesized compounds 4 and 5a-g was carried out against different bacterial strains like Ecoli, Staphylococcus aureus, Klebsiella pneumoniae, Bacillus Subtilis, and Pseudomonas aeruginosa by well diffusion method. A lawn of an overnight grown broth culture was prepared on Muller Hinton agar plates. The well was created using a borer and filled with samples to be tested (app $100 \mu \mathrm{m} / \mathrm{ml}$ ). The plates were kept in an incubator for $24 \mathrm{~h}$. The zone of inhibition was measured around the well (in $\mathrm{mm}$ ).

\section{RESULTS AND DISCUSSION}

In the present work a new series of Mannich bases (5a-g) of 5-(benzimidazol-2-ylthio) methyl)-1,3,4oxadiazole-2 $(3 \mathrm{H})$-thione 4 was synthesized by Mannich reaction of an active substrate 5-(benzimidazol2-ylthio) methyl)- 1,3,4-oxadiazole-2(3H)-thione 4 with formaldehyde and different secondary amines as 
RASĀYAN J. Chem.

Vol. 13 | No. 1 |370 - 376| January - March | 2020

described in the Scheme-1. The reaction steps to synthesize the target compounds are given in Scheme-1. The yield (\%) and the time (h) required for both the microwave irradiation method and the conventional method is compared in Table-1. TLC was used at every step to confirm the completion of the reaction. The structures of synthesized compounds $\mathbf{4}$ and $\mathbf{5 a - g}$ were subsequently evidenced by their FT-IR, 1H NMR and mass spectral analysis. Newly synthesized 5-((1H-benzimidazol-2-ylthio)methyl)-1,3,4oxadiazole-2(3H)-thione 4 and its Mannich bases 5a-g were assessed for antibacterial activity against different bacterial strains. Ciprofloxacin was designated as a standard drug. The observed antibacterial activities are shown in Table-2.<smiles>Sc1nc2ccccc2[nH]1</smiles>

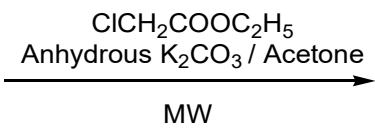<smiles>Sc1nc2ccccc2[nH]1</smiles>

2<smiles>CCOC(=O)CC</smiles>
3
Where R

$5 a=1$-morpholine

$5 \mathrm{~b}=1$-pyrolidine

$5 \mathrm{c}=-\mathrm{NH}\left(\mathrm{CH}_{3}\right)_{2}$

$5 \mathrm{~d}=-\mathrm{NH}\left(\mathrm{C}_{2} \mathrm{H}_{5}\right)_{2}$

$5 \mathrm{~d}=1$-piperidine

$5 \mathrm{f}=-\mathrm{N}$-methyl piperazine

$5 \mathrm{~g}=-\mathrm{N}$-ethyl piperazine<smiles>[R]Cn1nc(CSc2nc3ccccc3[nH]2)oc1=S</smiles>

5a-g

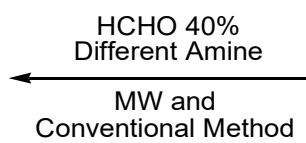

Conventional Method<smiles>S=c1[nH]nc(CSc2nc3ccccc3[nH]2)o1</smiles>

Scheme-1: Synthesis of Oxadiazole Derivative and its Mannich Bases

The new Mannich bases of 5-((1H-benzimidazol-2-ylthio)methyl)-1,3,4-oxadiazole-2(3H)-thione were synthesized in four steps as depicted in Scheme-1.

In acetone with anhydrous $\mathrm{K}_{2} \mathrm{CO}_{3}$, commercially available 2-Mercaptobenzimidazole was condensed with ethyl chloroacetate to give compound ethyl 2-(1H-benzimidazol-2-ylthio) acetate (2) under microwave radiation by reported method ${ }^{34}$.

Ammonolysis of ethyl 2-(1H-benzimidazol-2-ylthio) acetate (2) with hydrazine monohydrate solution in ethyl alcohol afforded 2-(1H-benzimidazol-2-ylthio) acetohydrazide (3) using microwave radiation by reported method ${ }^{34}$.

Table-1: Comparative Study for Microwave and Conventional Technique 4 and 5a-g

\begin{tabular}{|c|c|c|c|c|}
\hline \multirow[t]{3}{*}{ Product } & \multicolumn{2}{|c|}{ Conventional Method } & \multicolumn{2}{|c|}{ Microwave Irradiation (MW) } \\
\hline & \multirow[t]{2}{*}{ Time (h) } & \multirow[t]{2}{*}{${ }^{\mathrm{a}}$ Yield $(\%)$} & Condition & \multirow[t]{2}{*}{${ }^{\mathrm{a}}$ Yield $(\%)$} \\
\hline & & & Power(W)/Time(min) & \\
\hline 4 & 16 & 60 & $400 / 4.0$ & 88 \\
\hline $5 a$ & 2 & 72 & $350 / 1.0$ & 90 \\
\hline $5 b$ & 3 & 70 & $350 / 1.5$ & 86 \\
\hline $5 \mathrm{c}$ & 8 & 55 & $400 / 3.0$ & 70 \\
\hline $5 \mathrm{~d}$ & 9 & 54 & $400 / 3.5$ & 72 \\
\hline $5 \mathrm{e}$ & 6 & 60 & $400 / 2.0$ & 75 \\
\hline $5 f$ & 4 & 68 & $350 / 2.0$ & 85 \\
\hline $5 \mathrm{~g}$ & 4.5 & 65 & $350 / 2.0$ & 84 \\
\hline
\end{tabular}

${ }^{\mathrm{a}}$ Yield of isolated product

The alkaline solution of 2-(1H-benzimidazol-2-ylthio) acetohydrazide (3) in ethanol was treated with $\mathrm{CS}_{2}$ by both the conventional method and the microwave method. The conventional method of vigorous stirring at $30-35^{\circ} \mathrm{C}$ to synthesize desired compound 5-((1H-benzimidazol-2-ylthio)methyl)-1,3,4oxadiazole-2(3H)-thione (4) required long reaction time $14-16 \mathrm{~h}$ and gave $60 \%$ yield. While the 
RASĀYAN J. Chem.

Vol. 13 | No. 1 |370 - 376| January - March | 2020

microwave method gave $88 \%$ yield in just 4 minutes. The formation of compound 4 was evidenced by its mass $(\mathrm{m} / \mathrm{z})$ peak at $265\left[\mathrm{M}+\mathrm{H}^{+}\right]$. In ${ }^{1} \mathrm{H}$ NMR spectral analysis, the multiplets in the range $\delta 7.1-7.3 \mathrm{ppm}$ revealed aromatic protons and the singlet at $\delta 5.33 \mathrm{ppm}$ showed the presence of exchangeable NH proton in oxadiazole moiety. The absorption bands at 3349- $3129 \mathrm{~cm}^{-1}$ in the IR spectra also supported the existence of exchangeable $\mathrm{NH}$ proton in oxadiazole moiety. While the bands at $1672.5 \mathrm{~cm}^{-1}, 1523.8 \mathrm{~cm}^{-1}$, $1454 \mathrm{~cm}^{-1}$ were observed due to $-\mathrm{C}=\mathrm{N}-,-\mathrm{C}=\mathrm{C}-,-\mathrm{C}=\mathrm{S}$ and $-\mathrm{C}-\mathrm{H}$ bonds.

One-pot multicomponent Mannich reaction of 5-((1H-benzimidazol-2-ylthio)methyl)-1,3,4-oxadiazole$2(3 \mathrm{H})$-thione (4) with formaldehyde and different secondary amine gave target compounds 5a-g as mentioned in Scheme-1. The reactions performed using microwave radiations were completed within 1-4 minutes in high yield, while the conventional method required longer reaction time and gave low yield (Table 1). The formation of compounds $\mathbf{5 a - g}$ was confirmed by the corresponding mass $(\mathrm{m} / \mathrm{z})$ peak. The IR absorption bands at $1618 \mathrm{~cm}^{-1}$ were observed due to $\mathrm{C}=\mathrm{N}$ bond. Absorption bands at $1440 \mathrm{~cm}^{-1}$ and $1161 \mathrm{~cm}^{-1}$ represented C-N and C-O-C bonds respectively. ${ }^{1} \mathrm{H}$ NMR spectral peaks around $\delta$ 7.2- $7.8 \mathrm{ppm}$, $\delta$ 4.8-5.3 ppm and peaks in the region $\delta 1-3$ ppm affirmed the presence of aromatic protons, bridge $\mathrm{CH}_{2}$ protons and the aliphatic protons of secondary amines in the target compounds 5a-g respectively.

The newly synthesized compounds $\mathbf{4}$ and $\mathbf{5 a - g}$ were checked for antibacterial activity against different bacterial strains. The zone of inhibition ( $\mathrm{mm}$ ) of all the synthesized compounds $\mathbf{4}$ and $\mathbf{5 a - g}$ are presented in Table-2. Compound 5a with morpholinyl substituent showed good antimicrobial activity while 5b-e exhibited moderate activity. The presence of N-methyl and N-ethyl piperazinyl moiety in the target compounds showed much better inhibition activity. Ecoli, Staphylococcus aureus, and Bacillus Subtilis were resistant against compound 5c. Compound 5d was inactive against Ecoli, Bacillus Subtilis and Pseudomonas aeruginosa.

Table-2: Antibacterial Activity of Compounds $4 \& 5 \mathrm{a}-\mathrm{g}$

\begin{tabular}{c|c|c|c|c|c}
\hline \multirow{2}{*}{ Compound } & \multicolumn{5}{|c}{ Antimicrobial Activity (mm) } \\
\cline { 2 - 6 } & Ecoli & $\begin{array}{c}\text { Staphylococcus } \\
\text { aureus }\end{array}$ & $\begin{array}{c}\text { Klebsiella } \\
\text { pneumoniae }\end{array}$ & $\begin{array}{c}\text { Bacillus } \\
\text { Subtilis }\end{array}$ & $\begin{array}{c}\text { Pseudomonas } \\
\text { Aeruginosa }\end{array}$ \\
\hline 4 & 15 & 13 & 14 & 12 & 14 \\
\hline $5 \mathrm{a}$ & 18 & 15 & 20 & 16 & 12 \\
\hline $5 \mathrm{~b}$ & 16 & 11 & 15 & 10 & 16 \\
\hline $5 \mathrm{c}$ & - & - & 11 & - & - \\
\hline $5 \mathrm{~d}$ & - & 15 & 10 & 11 & 12 \\
\hline $5 \mathrm{e}$ & 12 & 14 & 12 & 15 & 18 \\
\hline $5 \mathrm{f}$ & 20 & 16 & 21 & 21 & 20 \\
\hline 5g & 22 & 14 & 18 & 25 & 24 \\
\hline Ciprofloxacin & 27 & 23 & 22 & & \\
\hline
\end{tabular}

\section{CONCLUSION}

A new compound 5-((1H-benzimidazol-2-ylthio)methyl)-1,3,4-oxadiazole-2(3H)-thione 4 and its derivatives 5-((1H-benzimidazol-2-ylthio) methyl)-3-(substituted)- 1,3,4-oxadiazole-2(3H)-thione 5a-g were successfully synthesized by the Mannich reaction under microwave irradiation with high yield and short reaction time. The spectroscopic investigations of compounds $\mathbf{4}$ and 5a-g supported the proposed structures for these compounds. The compound $\mathbf{4}$ and its Mannich bases 5a-g exhibited moderate to good antimicrobial activity.

\section{ACKNOWLEDGMENT}

The authors are grateful to the microbiology department of Seth Kesarimal Porwal College Kamptee India, for performing the antimicrobial activity. Authors are also thankful to Panjab University Chandigarh, India for performing FT-IR and ${ }^{1} \mathrm{H}$ NMR spectral studies.

\section{REFERENCES}

1. D. Kumaraswamy and V. Mallareddy, Rasayan Journal of Chemistry, 9 (2), 169(2016).

2. S. Triloknadh, C. V. Rao, K. Nagaraju, N. H. Krishna, C. V. Ramaiah, W. Rajendra, D. Trinath and Y. Suneetha, Bioorganic and Medicinal Chemistry Letters, 28, 1663(2018), DOI: 10.1016/j.bmcl.2018.03.030 
RASĀYAN J. Chem.

Vol. 13 | No. 1 |370 - 376| January - March | 2020

3. X. H. Lv, H. Liu, H., ZL. Ren, W. Wang, F. Tang and H. Q. Cao, Molecular Diversity, 23(2), 299(2019), DOI:10.1007/s11030-018-9873-9

4. Y. Liu, H. Xin, J. Yin, D. Yin, Z. Yang and J. Li, Journl of Molecular Structure, 1157,482(2017), DOI: $10.1016 /$ j.molstruc.2017.12.089

5. A. Dorababu, R. R. Kamble, A. A. Kamble, M. N. Kumbar,S. J. Shaikh and S. P. Netalkar, Chemistry Select, 4(10), 1(2019), DOI:10.1002/slct.201803933

6. D. J. Wang, Z. Hou, H. Xu, R. An, X. Su and C. Guo, Bioorganic and Medicinal Chemistry Letters, 28(22), 3574(2018), DOI:10.1016/j.bmcl.2018.06.035

7. H. I. Gul, M. Tugrak, M. Gul, S. Mazlumoglu, H. Sakagami, I. Gulcin and C. T. Supuran, Bioorganic Chemistry, 90, 103057(2019), DOI:10.1016/j.bioorg.2019.103057

8. S. Demirci and N. Demirbaş, Medicinal Chemistry Research, 28(11), 1945(2019), DOI:10.1007/s00044-019-02426-1

9. D. Li, Y. Tan, L. Peng, S. Li, N. Zhang, Y. Liu and H. Yan, Organic Letters, 20(16), 4959(2018), DOI: 10.1021/acs.orglett.8b02087

10. M. Tugrak, H.I. Gul, K. Bandow, H. Sakagami, I. Gulcin, Y. Ozkay and C. T. Supuran, Bioorganic Chemistry, 90, 103095(2019), DOI:10.1016/j.bioorg.2019.103095

11. Y. Guo, J. Fan, L. Qu, C. Bao, Q. Zhang, H. Dai and R. Yang, Industrial Crops Products, 141, 111762(2019), DOI: 10.1016/j.indcrop.2019.111762

12. S. Indira, G. Vinoth, M. Bharathi and K. S. Bharathi, Journal of Molecular Structure, 1198, 126886(2019), DOI:10.1016/j.molstruc.2019.126886

13. A. E. M. Noreljaleel, A. Wilhelm, S. L. Bonnet and J. H. van der Westhuizen, Journal of Natural Product, 81(1), 41(2018), DOI:10.1021/acs.jnatprod.7b00570

14. M. T. E. Sayed, M. A. M. Sh. El-Sharief, E. S. Zarie, N. M. Morsy, A. R. Elsheakh, A. Voronkov, V. Berishvili and G. S. Hassan, Bioorganic and Medicinal Chemistry Letters, 28(5), 952(2018), DOI: 10.1016/j.bmcl.2018.01.043

15. D. Tao, Y. Wang, X. Q. Bao, B. B. Yang, F. Gao, L. Wang, D. Zhang and L. Li, European Journal of Medicinal Chemistry, 173, 203(2019), DOI:10.1016/j.ejmech.2019.04.016

16. R. Aeluri, M. Alla, S. Polepalli, and N. Jain, European Journal of Medicinal Chemistry, 100, 18(2015), DOI:10.1016/j.ejmech.2015.05.037

17. R. Bhutani, D. P. Pathak, G. Kapoor, A. Hussain, R. Kant and Md. A. Iqbal, Bioorganic Chemistry, 77, 6(2018), DOI:10.1016/j.bioorg.2017.12.037

18. N. G. Li, S. L. Song, M. Z. Shen, Y. P. Tang, Z. H. Shi, H. Tang, Q. P. Shi, Y. F. Fu and J. A. Duan, Bioorganic \& Medicinal Chemistry, 20(24), 6919(2012), DOI:10.1016/j.bmc.2012.10.015.

19. M. Jeeva, G. V. Prabhu, M. S. Boobalan and C. M. Rajesh, The Journal of Physical Chemistry C, 119(38), 22025(2015), DOI: $10.1021 /$ acs.jpcc.5b05788

20. P. Jeyanthi, K. Sheela and P. Pazhanisamy, Rasayan Journal of Chemistry, 4(4), 890(2011).

21. K. Ramalingam, D. Ramesh and B. Sreenivasulu, Rasayan Journal of Chemistry, 12(2), 583(2019).

22. A. Ts. Mavrova, D. Yancheva, N. Anastassova, K. Anichina, J. Zvezdanovic, A. Djordjevic, D. Markovic and A. Smelcerovic, Bioorganic \& Medicinal Chemistry, 23(19), 6317(2015), DOI: $10.1016 / \mathrm{j} . \mathrm{bmc} .2015 .08 .029$

23. N. O. Anastassova, A. Ts. Mavrova, D. Y. Yancheva, M. S. K. Burdina, V. I. Tzankova, S. S. Stoyanov, B. L. Shivachev and R. P. Nikolova, Arabian Journal of Chemistry, 11(3), 353(2018), DOI: $10.1016 /$ j.arabjc. 2016.12 .003

24. A. A. Farahat, M. A. Ismail, A. Kumar, T. Wenzler, R. Brun, A. Baul, W. D. Wilson and D. W. Boykin, European Journal of Medicinal Chemistry, 143, 1590(2018), DOI:10.1016/j.ejmech.2017.10.056

25. F. Hernández-Luis, A. Hernández-Campos, R. Castillo, G. N. Vázquez, O. S. Arteche, M. H. Hernández and L. Y. Mulia, European Journal of Medicinal Chemistry, 45(7), 3135(2010), DOI:10.1016/j.ejmech.2010.03.050

26. K. C. S. Achar, K. M. Hosamani and H. R. Seetharamareddy, European Journal of Medicinal Chemistry, 45(5), 2048(2010), DOI:10.1016/j.ejmech.2010.01.029 
RASĀYAN J. Chem.

Vol. 13 | No. 1 |370 - 376| January - March | 2020

27. Q. Guan, C. Han, D. Zuo, M. Zhai, Z. Li, Q. Zhang, Y. Zhai, X. Jiang, K. Bao, Y. Wu and W. Zhang, European Journal of Medicinal Chemistry, 87, 306(2014), DOI:10.1016/j.ejmech.2014.09.071

28. J. F. Miller, E. M. Turner, K. S. Gudmundsson, S. Jenkinson, A. Spaltenstein, M. Thomson and P. Wheelan, Bioorganic \& Medicinal Chemistry Letters, 20(7), 2125(2010), DOI: $10.1016 / \mathrm{j} . \mathrm{bmcl} .2010 .02 .053$

29. N. Siddiqui, Md. S. Alam, R. Ali, M. Shahar Yar and O. Alam, Medicinal Chemistry Research, 25(7), 1390(2016), DOI: 10.1007/s00044-016-1570-6

30. V.V. Dabholkar and R. P. Gavande, Rasayan Journal of Chemistry, 3(4), 655(2010),

31. M. Y. Wani, A. Ahmad, R. A. Shiekh, K. J. AlGhamdi and A. J. F. N. Sobral, Bioorganic \& Medicinal Chemistry, 23(15), 4172(2015), DOI:10.1016/j.bmc.2015.06.053

32. B. K. Çavuşoğlu, L. Yurttaş and Z. Cantürk, European Journal of Medicinal Chemistry, 144, 255(2018), DOI:10.1016/j.ejmech.2017.12.020

33. J. Roh, G. Karabanovich, H. Vlčková, A. Carazo, J. Němeček, P. Sychra, L. Valášková, O. Pavliš, J. Stolaříková, V. Klimešová, K. Vávrová, P. Pávek and A. Hrabálek, Bioorganic \& Medicinal Chemistry, 25(20), 5468(2017), DOI:10.1016/j.bmc.2017.08.010

34. K. G. Desai and K. R. Desai, Bioorganic \& Medicinal Chemistry, 14(24), 8271(2006), DOI: 10.1016/j.bmc.2006.09.017

[RJC-5343/2019] 